\title{
Krim Ekstrak Buah Merah (Pandanus conoideus ) 10\% Sama Efektifnya dengan Krim Hidrokuinon 4\% dalam Mencegah Peningkatan Jumlah Melanin Kulit Marmut (Cavia porcellus) yang Dipapar Sinar Ultraviolet B
}

\author{
${ }^{1}$ Corazon H. Dumaria, ${ }^{2}$ AAGP Wiraguna, ${ }^{3}$ Wimpie Pangkahila
}

\author{
${ }^{1}$ Program Studi Magister Biomedik \\ ${ }^{2}$ Departemen Penyakit Kulit dan Kelamin \\ ${ }^{3}$ Bagian Andrologi dan Seksologi \\ Fakultas Kedokteran Universitas Udayana Denpasar \\ Email: corazon.hanna1@gmail.com
}

\begin{abstract}
This study was aimed to prove that administration of $10 \%$ redfruit extract cream could prevent the increase of skin melanin in guinea pig exposed to UVB and to compare this effect with $4 \%$ hydroquinone cream. This was a true experimental study using post test only control group design. Subjects were devided into three groups; each of 10 guinea pigs. Group 1 , the control group, was exposed to UVB and applied with basic cream. Group 2 was exposed to UVB and applied with $4 \%$ hydroquinone cream. Group 3 was exposed to UVB and applied with $10 \%$ redfruit extract cream. The total dose of UVB was $390 \mathrm{~mJ} / \mathrm{cm} 2$ given for 2 weeks. The amount of melanin was calculated using the percentage of the pixel area of melanin and was compared with the pixel areas of all epidermal tissues. The results showed that the highest percentage of melanin area was in group $1(19.78 \% \pm 3.79 \%)$. The percentage of melanin area in group 3 was $1.25 \% \pm 0.76 \%$ meanwhile in group 2 was $0.85 \% \pm 0.37 \%$. There were significant differences in melanin percentage between the control group and group 2 as well as group $3(P<0.05)$. There was no significant difference in melanin percentage between group 2 and group $3(P>0.05)$. Conclusion: The 10\% redfruit extract cream could prevent the increase of skin melanin in guinea pig exposed to UVB as effectively as the $4 \%$ hydroquinone cream.

Keywords: redfruit extract cream, melanin, UVB
\end{abstract}

\begin{abstract}
Abstrak: Penelitian ini bertujuan untuk membuktikan efek pemberian krim ekstrak buah merah $10 \%$ dalam mencegah peningkatan jumlah melanin kulit marmut yang dipapar sinar UVB dan perbandingannya dengan krim hidrokuinon $4 \%$. Jenis penelitian ialah eksperimental murni dengan post test only control group design. Sampel terdiri dari tiga kelompok dengan jumlah sampel 10 ekor marmut jantan tiap kelompok. Kelompok 1 yaitu kelompok kontrol, diberi paparan sinar UVB dan diolesi krim dasar. Kelompok 2 diberi paparan sinar UVB dan diolesi krim hidrokuinon 4\%. Kelompok 3 diberi paparan sinar UVB dan diolesi krim ekstrak buah merah 10\%. Dosis total UVB yaitu $390 \mathrm{~mJ} / \mathrm{cm} 2$ diberikan selama 2 minggu. Jumlah melanin dihitung dengan persentase pixel luas area melanin dibandingkan dengan pixel seluruh jaringan epidermis. Hasil penelitian menunjukkan jumlah melanin tertinggi pada kelompok $1(19,78 \pm 3,79 \%)$ dan terendah pada kelompok $2(0,85 \pm 0,37 \%)$, sedangkan jumlah melanin pada kelompok 3 di antara keduanya $(1,25 \pm 0,76 \%)$. Terdapat perbedaan bermakna antara kelompok 1 dengan kelompok 2 dan $3(P<0,05)$. Tidak terdapat perbedaan bermakna antara kelompok 2 dan 3 dalam mencegah peningkatan jumlah melanin $(P>0,05)$. Simpulan: Krim ekstrak buah merah $10 \%$ dapat mencegah peningkatan jumlah melanin kulit marmut yang dipapar sinar UVB sama efektif dengan krim hidrokuinon $4 \%$.
\end{abstract}

Kata kunci: krim ekstrak buah merah, melanin, UVB 
Kulit merupakan organ terluar dan terluas pada tubuh manusia yang merupakan target utama dari pengaruh lingkungan antara lain radiasi ultra violet (UV), obat, dan polusi udara yang merupakan faktor eksternal, sedangkan sebagai faktor internal yaitu faktor genetik, ras, hormonal serta reactive oxygen species (ROS) dan radikal bebas yang dihasilkan terus menerus selama proses metabolisme sel. ${ }^{1}$

Paparan sinar ultraviolet B (UVB) memiliki panjang gelombang 290-320 nm dan mengakibatkan delayed pigmentary darkening. Pada tahap ini terdapat peningkatan aktivitas enzim tirosinase dan produksi melanin, menigkatnya jumlah melanosit dan penyebaran melanin menuju keratinosit. Pigmentasi berlangsung sejak 2-3 hari setelah pemaparan dan menetap dalam 10-14 hari. ${ }^{2}$ Secara histopatologik, hiperpigmentasi yang terjadi dapat disebabkan oleh peningkatan jumlah melanin di epidermis. Proses pembentukan melanin di melanosom bermula dari hidroksilasi Ltirosin menjadi L-dopa serta oksidasi Ldopa menjadi dopakuinon. Semua proses ini membutuhkan enzim tirosinase, dan polimerisasi dopakuinon akan membentuk melanin. Enzim tirosinase bekerja langsung pada saat distimulasi oleh sinar UV. Selain itu, paparan UVB pada kulit mengakibatkan penurunan aktivitas antioksidan endogen pada lapisan kulit antara lain glutation peroksidase (GSH), superoxide dismutase (SOD), katalase, dan ubiquinol. ${ }^{3}$ Paparan UVB meng-hasilkan radikal bebas seperti hidrogen peroksidase, anion superoksida, nitrik oksida (NO) sehingga dapat menimbulkan terjadinya reactive oxygen species (ROS). ${ }^{1}$

Dewasa ini banyak orang melakukan tindakan pencegahan dengan cara menggunakan tabir surya, pemberian antioksidan, ${ }^{4}$ serta vitamin dan nutrisi ${ }^{3}$ untuk mencegah terjadinya melasma. Pengobatan topikal dapat dilakukan dengan pemberian golongan inhibitor tirosinase seperti hidrokuinon, retinoid, kombinasi keduanya, atau kombinasi hidrokuinon dengan asam askorbat. ${ }^{5}$

Hidrokuinon masih merupakan terapi utama untuk melasma ${ }^{6}$ yang memiliki mekanisme kerja sebagai penghambat kerja enzim tirosinase, merusak melanosit secara langsung, mempercepat degradasi melanosom, serta menghambat sintesis enzim melanogenesis. ${ }^{7}$ Penghambatan oleh hidrokuinon bersifat reversibel, ${ }^{8}$ namun bahan ini memiliki efek samping toksik terhadap melanosit (sitotoksik). ${ }^{6}$ Akibat efek samping tersebut penggunaan hidrokuinon saat ini sudah mulai sangat dibatasi. Berdasarkan hal tersebut, maka perlu dicari bahanbahan terapi hiperpigmentasi lain yang bersifat alami dan bila memungkinkan memiliki efek samping yang lebih sedikit.

Buah merah (Pandanus conoideus) merupakan buah tradisional dari Papua yang tinggi kandungan antioksidannya. Berdasarkan hasil analisis fitokimia dan pemeriksaan kuantitatif yang dilakukan di Fakultas Teknologi Pertanian Universitas Udayana ekstrak buah merah mengandung kadar senyawa bioaktif antara lain flavonoid sebesar 238,63 mg/100gr QE, tannin $600,71 \mathrm{mg} / 100 \mathrm{~g}$ TAE, vitamin C sebesar $958,18 \mathrm{mg} / 100 \mathrm{~g}$, beta karoten sebesar 287416,99 ug/100g, dan kapasitas antioksidan sebesar 372,15 mg/L GAEAC.

Ekstrak buah merah mengandung beberapa senyawa seperti tanin, vitamin $C$, beta karoten, serta flavonoid yang berefek antioksidan yang mampu mencegah terbentuknya ROS. Selain itu, tanin dan flavonoid juga berefek menghambat proses melanogenesis sebagai inhibitor tirosinase. ${ }^{9}$

Penelitian pendahuluan yang telah dilakukan terhadap kulit marmut yang dipapar sinar UVB dan dioles krim ekstrak buah merah konsentrasi $2 \%, 4 \%, 5 \%$, dan $10 \%$ menunjukkan bahwa jumlah melanin pada kelompok yang diberikan krim ekstrak buah merah $10 \%$ ialah yang paling sedikit dan setara dengan jumlah melanin pada kelompok yang diberikan hidrokuinon $4 \%$. Berdasarkan hasil penelitian tersebut, konsentrasi ekstrak buah merah yang digunakan untuk penelitian ini ialah $10 \% .^{10}$

Penelitian ini bertujuan untuk mengetahui efek ekstrak buah merah dalam mencegah peningkatan jumlah melanin akibat paparan sinar UVB pada kulit marmut (Cavia porcellus) secara in vivo. 
Untuk mengetahui efektivitasnya maka ekstrak buah merah dibandingkan dengan hidrokuinon $4 \%$.

\section{METODE PENELITIAN}

Jenis penelitian ini ialah eksperimental dengan post test only control group design. Sampel yang digunakan dalam penelitian ialah marmut (Cavia porcellus), jantan, strain lokal, umur 3 bulan, berat 300-350 gr, dan sehat. Jumlah sampel yang digunakan dihitung berdasarkan rumus Federer $^{11}$ dan diperoleh jumlah sampel per kelompok sebanyak 10 ekor. Terdapat tiga kelompok sampel dengan jumlah keseluruhan ialah 30 ekor marmut. Variabel yang digunakan meliputi variabel bebas (krim ekstrak buah merah $10 \%$, krim dasar, dan krim hidrokuinon 4\%); variabel tergantung (jumlah melanin); variabel kendali (strain marmut jantan strain lokal, umur, warna, genetik, pakan marmut, aktivitas marmut, kesehatan marmut, berat badan marmut, biopsi jaringan kulit marmut, melanin); dan variabel kondisi (paparan sinar UVB).

Sebanyak 30 ekor marmut diadaptasi selama satu minggu kemudian secara random marmut dibagi menjadi tiga kelompok yaitu: kelompok kontrol P0 (kontrol negatif), kelompok P1 (kontrol positif), dan kelompok P2 (kelompok perlakuan), masing-masing kelompok terdiri dari 10 marmut. Marmut dari semua kelompok dicukur bulu punggungnya, kemudian dioleskan bahan dasar krim pada kelompok P0; krim hidrokuinon $4 \%$ pada kelompok P1; dan krim ekstrak buah merah $10 \%$ pada kelompok P2. Masing-masing krim dioleskan sebanyak $0,2 \mathrm{mg} / \mathrm{cm} 2$ luas permukaan kulit marmut.

Paparan UVB diberikan terhadap semua kelompok sebanyak 3 kali seminggu (Senin, Rabu, dan Jumat) dengan 65 $\mathrm{mJ} / \mathrm{cm} 2$ setiap kali paparan, sehingga total sinar UVB yang diterima oleh masingmasing marmut tersebut ialah $390 \mathrm{~mJ} / \mathrm{cm} 2$ selama dua minggu. ${ }^{12}$ Krim dasar, krim hidrokuinon $4 \%$, krim ekstrak buah merah $10 \%$ dioleskan 2 kali sehari, yaitu 20 menit sebelum dipapar (untuk memberikan waktu absorpsi bahan topikal masuk ke dalam kulit) dan 4 jam setelah penyinaran (terbentuknya ROS dimulai 4 jam setelah paparan). Aplikasi bahan topikal tetap dilakukan pada hari tanpa penyinaran. Setelah 48 jam penyinaran terakhir, semua marmut dari ketiga kelompok diistirahatkan untuk menyingkirkan pengaruh penyinaran akut, kemudian dilakukan euthanasia, diambil jaringan kulit punggungnya, dan dimasukkan dalam larutan formalin $40 \%$. Jaringan kulit marmut dibuat sediaan histologik untuk pemeriksaan jumlah melanin.

Jumlah melanin dihitung dengan metode analisis cepat secara digital terhadap sediaan preparat kulit yang diwarnai dengan pulasan Masson-Fontana. Setiap sediaan preparat difoto dengan menggunakan kamera Optilab Pro dan mikroskop Olympus Cx40 dengan pembesaran objektif 40 kali. Masing-masing preparat difoto 3 kali, yaitu sisi kiri, tengah, dan sisi kanan sediaan. Hasil foto disimpan dalam format JPEG. Penghitungan jumlah melanin dilakukan dengan piranti lunak Adobe Photoshop CS3 versi 9.0.

\section{HASIL PENELITIAN}

Hasil penelitian ini menunjukkan bahwa rerata jumlah melanin pada kelompok kontrol negatif yang diberikan penyinaran UVB dan bahan dasar krim (P0) ialah $19,78 \pm 3,79 \%$, sedangkan pada kelompok perlakuan 2 yang diberikan penyinaran UVB dan krim hidrokuinon $4 \%$ (P1) ialah 0,85 $\pm 0,37 \%$ (Tabel 1). Uji signifikansi dengan menggunakan Least Significance Difference (LSD) test menunjukkan bahwa terdapat perbedaan nyata antara kelompok kontrol dengan kelompok P1 $(P<0,05)$ (Tabel 2) yang sesuai dengan teori yang telah disampaikan bahwa krim hidrokuinon $4 \%$ sangat efektif dalam mencegah peningkatan melanin pada marmut yang dipapar sinar UVB.

Hasil penelitian menunjukkan bahwa penggunaan krim ekstrak buah merah dengan konsentrasi $10 \%$ efektif mencegah peningkatan melanin. Kelompok kontrol yang diberikan penyinaran UVB dan bahan dasar krim (P0) menunjukkan jumlah melanin sebesar $19,78 \pm 3,79 \%$, sedangkan 
pada kelompok perlakuan yang diberikan penyinaran ultraviolet $\mathrm{B}$ dan krim ekstrak buah merah $10 \% \quad(\mathrm{P} 2)$ hanya sebesar $1,25 \pm 0,76 \%(P<0,05)$ (Tabel 1). Hal ini menunjukkan bahwa krim ekstrak buah merah $10 \%$ sangat efektif mencegah peningkatan melanin akibat sinar UVB dengan efektifitas yang sama dengan krim hidrokuinon $4 \%$. Hal ini terbukti dari hasil analisis Least Significance Difference (LSD) test yang menunjukkan bahwa tidak terdapat perbedaan antara kelompok P1 dan kelompok P2 $(P>0,05)$ (Tabel 2).

Hasil pemeriksaan histopatologik memperlihatkan pigmen melanin (berwarna hitam) yang jelas tampak lebih banyak pada kelompok kontrol (P0) dibandingkan kelompok perlakuan P1 dan P2 (Gambar 1).

Tabel 1. Rerata jumlah melanin

\begin{tabular}{cccc}
\hline Kelompok & n & Rerata \pm SB $(\%)$ & $\boldsymbol{p}$ \\
\hline Kelompok P0 & 10 & $19,78 \pm 3,79$ & \\
Kelompok P1 & 10 & $0,85 \pm 0,37$ & 0,000 \\
Kelompok P2 & 10 & $1,25 \pm 0,76$ & \\
\hline n= jumlah sampel, SB $=$ simpangan baku, $p=$ signifikansi
\end{tabular}

$\mathrm{n}=$ jumlah sampel, $\mathrm{SB}=$ simpangan baku, $p=$ signifikansi

Tabel 2. Analisis LSD antar kelompok

\begin{tabular}{cccc}
\hline Kelompok I & Kelompok II & $\begin{array}{c}\text { Rerata } \\
\text { Perbedaan }\end{array}$ & $\boldsymbol{p}$ \\
\hline \multirow{2}{*}{ Kelompok P0 } & Kelompok P1 & $1.39720^{*}$ & 0,000 \\
& Kelompok P2 & $1.26660^{*}$ & 0,000 \\
\hline \multirow{2}{*}{ Kelompok P1 } & Kelompok P0 & $-1.39720^{*}$ & 0,000 \\
& Kelompok P2 & -0.13060 & 0,167 \\
\hline \multirow{2}{*}{ Kelompok P2 } & Kelompok P0 & $-1.26660^{*}$ & 0,000 \\
& Kelompok P1 & 0.13060 & 0,167 \\
\hline
\end{tabular}

*Berbeda secara statistik $(\mathrm{p}<0,05)$ diuji dengan menggunakan Least Significance

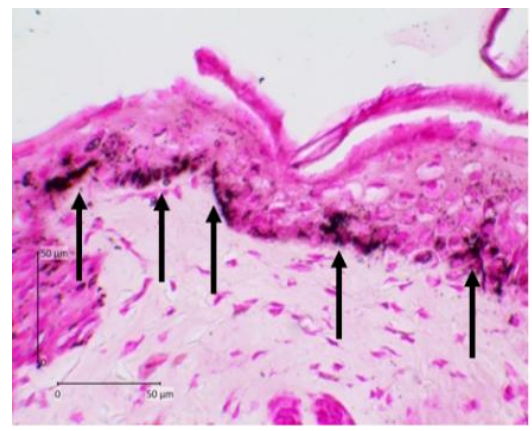

Kelompok P0

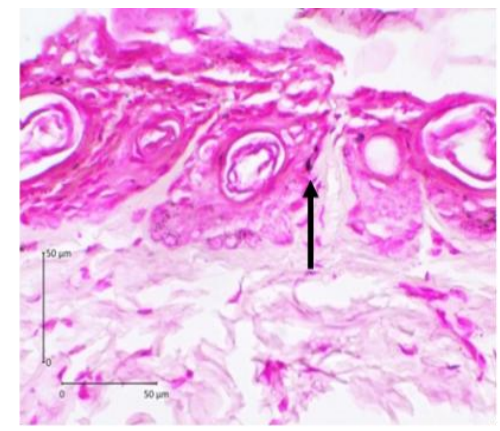

Kelompok P1

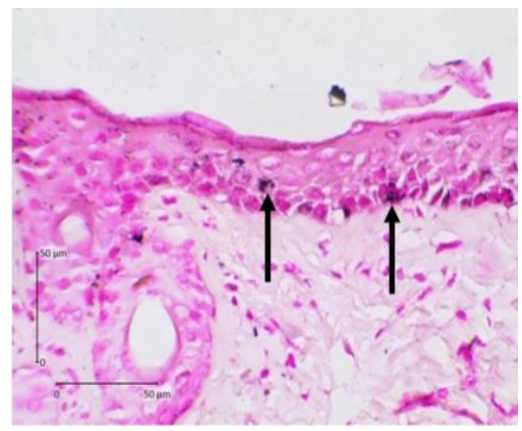

Kelompok P2

Gambar 1. Gambaran melanin kulit marmut dengan pewarnaan Masson-Fontana (panah hitam) 


\section{BAHASAN}

Secara garis besar, radiasi sinar UV menyebabkan pigmentasi dengan beberapa cara yaitu meningkatkan kerja enzim melanogenik, kerusakan DNA yang akan menstimulasi melanogenesis, meningkatkan transfer melanosom menuju keratinosit, dan aktivitas dendritik sel melanosit. ${ }^{13}$ Radiasi sinar UV dapat memicu terjadinya ROS yang selanjutnya memicu keluarnya NO, protein kinase, melanocyte stimulating hormone (MSH), dan prostaglandin E2 (PGE2) yang dapat merangsang terjadinya proses melanogenesis. ${ }^{14}$

Secara lebih rinci, paparan sinar UV mengaktifkan melanogenesis melalui empat reseptor. Pertama, stem cell factor (SCF) mengaktifkan cKIT reseptor, diikuti dengan aktivasi mitogen-activated protein kinase (MAPK) dan meningkatkan microphthalmia-associated transcription factor (MITF). Kadar MITF yang tinggi akan diikuti oleh transkripsi enzim tirosinase, TRP1, TRP2 dan akhirnya sintesis melanin. Kedua, adrenalin dan noradrenalin ditangkap oleh reseptor adrenergik yang akan mengaktivasi 3',5'-cyclic adenomonophosphate (cAMP) diikuti oleh aktivasi cAMP response element-binding protein (CREB) dan Protein Kinase A (PKA) dan meningkatkan MITF. Ketiga, radiasi UV akan meningkatkan $\alpha \mathrm{MSH}$ (melanocyte stimulating hormon) yang terikat dengan melanocortin-1 receptor (MC1R) diikuti dengan aktivasi cAMP, dan peningkatan MITF. Nitric oxyde radicals mengaktivasi guanyl cyclase yang akan mengaktivasi Cyclic Guanosine monophosphate (cGMP) dan MITF. Keempat, Wnt receptor mengaktivasi glycogen synthase kinase $3 \beta$ $(\mathrm{G} 5 \mathrm{~K} 3 \beta)$ yang meningkatkan $\beta$-catekin dan lymphocyte enhancer factor (LEF)/TCA kompleks dan mengaktifkan MITF. ${ }^{15}$

Hidrokuinon merupakan terapi yang paling banyak dipakai untuk penanganan hiperpigmentasi pada saat ini. Konsentrasi dimulai dari $2 \%$ hingga kurang dari $10 \%{ }^{6}$ dan memiliki mekanisme kerja dengan cara menghambat enzim tirosinase, merusak melanosit secara langsung, mempercepat degradasi melanosom, dan menghambat sintesis enzim melanogenesis. ${ }^{7}$ Hidrokuinon juga menghambat metabolisme sel secara reversibel dengan memengaruhi kerja sintesis RNA dan DNA. Efek hidrokuinon dapat menurunkan lesi hiperpigmentasi hingga 90\% sehingga dapat mencegah peningkatan jumlah melanin pada lapisan epidermis. ${ }^{6}$ Pada penelitian ini, krim hidrokuinon konsentrasi $4 \%$ digunakan sebagai kontrol positif.

Walaupun efektivitas hidrokuinon sangat baik dalam mencegah melanogenesis akibat paparan UVB, penggunaannya saat ini sudah mulai sangat dibatasi karena dalam jangka panjang penggunaan hidrokuinon dapat menimbulkan efek samping yaitu menimbulkan iritasi, rebound phenomenon, dan okronosis. Terkait hal ini, peneliti tertarik pada aplikasi krim ekstrak buah merah yang mengandung senyawa antioksidan dengan kandungan yang cukup tinggi. Seperti yang telah dipaparkan sebelumnya, penggunaan konsentrasi $10 \%$ pada penelitian ini didasarkan atas hasil penelitian pendahuluan yang menunjukkan bahwa jumlah melanin pada kelompok yang diberikan krim ekstrak biji buah merah $10 \%$ yang paling sedikit dan setara dengan jumlah melanin pada kelompok yang diberikan hidrokuinon. ${ }^{10}$

Hingga saat ini, belum ada penelitian yang menggunakan ekstrak buah merah untuk mencegah peningkatan melanin akibat paparan UVB, baik secara in vitro maupun in vivo, sehingga hasil penelitian ini tidak dapat dibandingkan dengan penelitian sebelumnya. Selain itu, untuk mengetahui efek penggunaan jangka panjangnya perlu dilakukan penelitian lebih lanjut serta uji klinis sehingga dapat digunakan sebagai pencegahan maupun pengobatan kelainan hiperpigmentasi pada masyarakat luas.

Hasil analisis fitokimia yang dilakukan di Fakultas Teknologi Pertanian Universitas Udayana mendapatkan bahwa ekstrak buah merah mengandung steroid, fenolik, dan flavonoid. Pemeriksaan kuantitatif kadar senyawa bioaktif di dalam ekstrak buah merah menunjukkan kadar flavonoid sebesar 238,63 mg/100gr QE, tannin 600,71 mg/100g TAE, vitamin C 958,18 
$\mathrm{mg} / 100 \mathrm{~g}$, beta karoten $287416,99 \mathrm{ug} / 100 \mathrm{~g}$, dan kapasitas anti-oksidan sebesar 372,15 $\mathrm{mg} / \mathrm{L}$ GAEAC.

Antioksidan mencegah terjadinya ROS yang dapat memicu terjadinya proses melanogenesis sehingga dengan dihambatnya proses melanogenesis maka peningkatan jumlah melanin yang dipicu oleh sinar UVB tidak terjadi. Kapasitas antioksidan pada ekstrak buah merah yang digunakan dalam penelitian ini ialah 372,15 mg/L GAEAC. Penelitian sebelumnya yang dilakukan oleh Siahaan $^{16}$ menggunakan ekstrak kulit delima merah yang mengandung kapasitas antioksidan sebesar 132,45 $\mathrm{mg} / \mathrm{L}$ GAEAC untuk mencegah peningkatan melanin akibat paparan UVB pada marmut. Selain itu, terdapat penelitian lain yang bertujuan untuk mencegah peningkatan melanin akibat paparan UVB dengan menggunakan ekstrak biji mengkudu yang mengandung kapasitas antioksidan sebesar 48,924mg/L GAEAC. ${ }^{17}$ Kapasitas antioksidan dalam penelitian ini lebih besar dibandingkan dua penelitian sebelumnya.

Kandungan flavonoid pada buah merah dapat bekerja langsung menghambat enzim tirosinase sehingga buah merah dapat menjadi bahan pencegah timbulnya pigmentasi kulit akibat paparan sinar UV. ${ }^{9}$ Tanin bersifat sebagai antioksidan dan juga berkemampuan sebagai anti tirosinase. ${ }^{18}$ Oleh karena dihambatnya proses biosintesis melanin maka peningkatan produksi melanin tidak terjadi setelah paparan sinar UVB. Vitamin $\mathrm{C}$ disebut sebagai antioksidan karena mendonorkan elektronnya sehingga ROS dinetralisir dan proses melanogenesis dapat dihambat, dan peningkatan jumlah melanin tidak terjadi. ${ }^{19}$

Penambahan zat antioksidan ke dalam krim semakin banyak digunakan. Antioksidan topikal berguna untuk menekan efek ROS pada kulit. Selain itu, pemberian antioksidan dalam krim dapat meningkatkan kelembaban kulit serta menurunkan transepidermal water loss. ${ }^{20}$ Berdasarkan hasil penelitian ini, dapat disimpulkan bahwa ekstrak buah merah terbukti dapat mencegah peningkatan jumlah melanin pada kulit marmut yang dipapar sinar UVB.
Hal ini dikarenakan ekstrak buah merah mengandung beberapa senyawa yang mempunyai efek sebagai antioksidan dan menghambat enzim tirosinase sehingga daapt mencegah peningkatan jumlah melanin.

\section{SIMPULAN}

Berdasarkan hasil penelitian ini dapat disimpulkan bahwa pemberian krim ekstrak buah merah (Pandanus conoideus) 10\% memiliki efektivitas yang sama dengan krim hidrokuinon $4 \%$ dalam mencegah peningkatan jumlah melanin kulit marmut (Cavia porcellus) yang dipapar sinar UVB.

\section{DAFTAR PUSTAKA}

1. Icihashi M, Ando H, Yshida M, Niki Y, Matsui M. Photoaging of the skin. Anti-Aging Medicine. 2009;6(6):46-59.

2. Baumann L, Saghari S. Photoaging. In: Baumann L, Saghari S, Weisberg E, editors. Cosmetic Dermatology (2nd ed). New York: McGrawHill, 2009; p. 34-40.

3. Pandel R, Poljsak B, Godic A, Dahmane R. Skin photoaging and the role of antioxidants in its prevention. ISRN Dermatology. 2013;2013. Article ID 930164.

4. Grether-Beck S, Marini A, Jaenicke T, Krutmann J. Effective photoprotection of human skin against infrared A radiation by topically applied antioxidants: results from a vehicle controlled, double-blind, randomized study. Photochem Photobiol. 2015;91(1):248-50.

5. Desai SR. Hyperpigmentation therapy: a review. J Clin Aesthet Dermatol. 2014;7(8):13-7.

6. Baumann L, Alleman IB. Depigmentation agent. In: Baumann L, Saghari S, Weisberg E, editors. Cosmetic Dermatology (2nd ed). New York: McGraw Hill, 2009; p. 280-8.

7. Bruce S. Safety and efficacy of a novel multimodality hydroquinone-free skin brightener over six months. J Drugs Dermatol. 2013;12(3):S27-31.

8. Bandyopadhyay D. Topical treatment of melasma. IJD. 2009;54(4):303-9.

9. Chang TS. An update review of tyrosinase inhibitors. Int J Mol Sci. 2009; 10(6):2440-75. 
10. Dumaria CH. Pemberian krim ekstrak buah merah (Pandanus conoideus) mencegah peningkatan jumlah melanin kulit marmut yang disinari UVB. 2017 (Unpublished).

11. Federer WT. Statistical Designand Analysis for Intercropping Experiments. New York: Springer, 2008; p. 30-3.

12. Lee TH, See JO, Baek SH, Kim SY. Inhibitory effects of resveratrol on melanin synthesis in ultraviolet Binduced pigmentation in guinea pig skin. Biomol Ther (Seoul). 2014; 22(1):35-40.

13. Kindred C, Halder RM. Pigmentation and skin color. In: Draelos ZD, editor. Cosmetic Dermatology Products and Procedures (1st ed). New Jersey: Wiley-Blackwell, 2010; p. 27-35.

14. Costin GE, HearingVJ. Human skin pigmentation: melanocytes modulate skin color in response to stress. FASEB J. 2007;21(4):976-94.

15. Li A. The biology of melanocyte and melanocyte stem cell. Acta Biochim Biophys Sin (Shanghai). 2014;46(4): 255-60.
16. Siahaan R. Pemberian krim ekstrak kulit delima merah mencegah peningkatan jumlah melanin kulit marmut yang disinari UVB [Thesis]. Denpasar: Universitas Udayana; 2016.

17. Sofiana R. Pemberian krim biji mengkudu (Morinda citrifolia) mencegah peningkatan jumlah melanin kulit marmut yang disinari UVB [Thesis]. Denpasar: Universitas Udayana; 2016.

18. Shimogaki H, Tanaka Y, Tamai H, Masuda M. In vitro and in vivo evaluation of ellagic acid on melanogenesis inhibition. Int J Cosmet Sci. 2000;22(4):291-303.

19. Padayatty SJ, Katz A,Wang Y, Eck P, Kwon O, Lee JH, Chen S, et al. Vitamin $\mathrm{C}$ as an antioxidant: evaluation of is role in disease prevention. $\mathrm{J}$ Am Coll Nutr. 2003;22(1):18-35.

20. Campos PM, Gonçalves GM, Gaspar LR. In vitro antioxidant activity and in vivo efficacy of topical formulations containing vitamin $\mathrm{C}$ and its derivatives studied by non-invasive methods. Skin Res Technol. 2008; 14(3):376-80. 